\title{
BETON MEMADAT SENDIRI RAMAH LINGKUNGAN MENGGUNAKAN LIMBAH SERBUK BETON, LIMBAH SERBUK BATU BATA DAN LIMBAH DEBU PEMOTONGAN MARMER
}

\author{
Candra Latu Mowo \\ Program Studi Teknik Sipil, Fakultas Teknik, Universitas Tunas Pembangunan, Surakarta \\ candralatu123@gmail.com \\ Dian Arumningsih DP \\ Program Studi Teknik Sipil, Fakultas Teknik, Universitas Tunas Pembangunan, Surakarta \\ diandindin82@gmail.com
}

\begin{abstract}
Abstrak
Pertumbuhan dan perkembangan infrastruktur saat ini sangat pesat serta proses produksi semen juga menghasilkan banyak karbondioksida yang berperan penting dalam pemanasan global yang terjadi di dunia ini. Self compacting concrete merupakan salah satu inovasi terbesar yang terjadi di bidang konstruksi, dimana beton ini mempunyai daya kerja yang tinggi tetapi juga tidak mengabaikan kuat tekan. Oleh karena itu, diperlukan material baru yang berkelanjutan untuk menggantikan produksi semen dan substitusi agregat halus baru, tetapi material ini juga diperlukan untuk kemampuan kerja yang diperlukan untuk membuat beton pemadatan sendiri. Konsep Green concrete, pemanfaatan serbuk limbah bata, dan serbuk limbah beton, dapat menjadi solusi untuk menggantikan sebagian semen dan limbah debu marmer juga untuk substitusi agregat halus. Penelitian ini self compacting concrete diperoleh dengan menggunakan (waste marble dust) yang menggantikan substitusi agregat pasir 30\%, serta limbah serbuk beton (concrete waste powder), dan limbah batu bata (brick waste powder) yang menggantikan $15 \%, 15 \%$, limbah beton dengan unsur utama kalsium oksida $(\mathrm{CaO})$ dan limbah serbuk batu bata yang memiliki kandungan $(\mathrm{SiO})$ dapat digunakan sebagai bahan tambahan ataupun pengganti sebagian semen dalam pembuatan beton. Pengukuran slump flow test dilakukan dengan mengacu pada aturan SNI 1972-2008 dan workability self compacting concrete ini juga memenuhi persyaratan yang dibutuhkan. Sehingga mendapatkan kesimpulan dapat menjadi sumber referensi dengan memanfaatkan limbah di Indonesia, mudah didapat, dan efektif.
\end{abstract}

Kata kunci: Beton memadat sendiri, limbah debu pemotongan marmer, serbuk limbah batu bata, serbuk limbah beton

\begin{abstract}
The growth and development of infrastructure is currently very rapid and the cement production process also produces a lot of carbon dioxide which plays an important role in global warming that is happening in this world. Self compacting concrete is one of the biggest innovations in the construction sector, where this concrete has high workability but does not neglect compressive strength. Therefore, new sustainable materials are needed to replace cement production and substitution of new fine aggregates, but these materials are also required for the workability required to make self-compacting concrete. The concept of Green concrete, the use of brick waste powder, and concrete waste powder, can be a solution to partially replace cement and marble dust waste as well as to substitute fine aggregate. In this study, self-compacting concrete was obtained by using (waste marble dust) which replaced $30 \%$ of sand aggregate, as well as concrete waste powder (concrete waste powder), and brick waste (brick waste powder) which replaced $15 \%, 15 \%$, concrete waste. with the main element calcium oxide $(\mathrm{CaO})$ and brick powder waste containing $(\mathrm{SiO})$ can be used as an additive or partial replacement of cement in the manufacture of concrete. The slump flow test measurement is carried out by referring to
\end{abstract}


the 1972-2008 SNI rules, and the workability of self compacting concrete also meets the required requirements. So that it can be concluded that it can be a reference source by utilizing waste in Indonesia, easy to obtain, and effective.

Keywords: Self-compacting concrete, marble cutting dust waste, brick waste powder, concrete waste powder.

\section{PENDAHULUAN}

Beton saat ini merupakan salah satu bahan konstruksi yang paling banyak digunakan di dunia sehingga menjadi peluang untuk membuat aplikasi yang inovatif, Self Compacting Concrete (SCC) merupakan salah satu aplikasi inovatif dibandingkan beton biasa. Dengan meminimalisir semen, SCC bisa lebih murah dan mengurangi dampak lingkungan dibandingkan beton biasa. Mengingat delapan hingga 10 persen dari total emisi $\mathrm{CO} 2$ dunia berasal dari pembuatan semen (Suhendro, 2014). Gas pemanasan global berkurang dengan mengganti semen yang menggunakan bahan kandungan dan bahan limbah serupa. Serbuk limbah bata dan limbah beton dalam jumlah besar yang dihasilkan dari lokasi konstruksi dan pembongkaran sebagian besar dikirim ke tempat pembuangan sampah atau lokasi reklamasi untuk dibuang, dan juga diperlukan sebagai substitusi agregat halus. Serbuk beton bekas merupakan akselerator yang menjanjikan untuk hidrasi semen. Itu bisa meningkatkan kuat tekan dalam 24 jam (Wang, Yao, dan Stephan, 2019). Lakum (2009); Kencanawati dan Merdana (2012) dan Susanti (2003) juga melakukan penelitian dengan menggunakan bubuk limbah batu bata, dan limbah debu marmer yang juga mengandung kandungan silika diatas 80\% (Muntohar AS, 2008) sebagai bahan tambahan dalam pembuatan beton dengan hasil meningkatkan kuat tekan, menurunkan porositas dan daya serap air kebawah dalam campuran serbuk limbah batako. Dalam praktik di lapangan, semakin meningkatnya jumlah tulangan yang ada maka akan memersulit campuran beton melewati tulangan-tulangan tersebut, meningkatkan resiko beton tidak mengalami pemadatan yang sempurna, dan membutuhkan waktu yang cukup lama. Untuk mengatasi masalah tersebut inovasi dapat dianggap unsur pembangunan berkelanjutan karena ramah lingkungan dan sedang banyak digunakan dalam praktek green building. Beton dengan pemanfaatan limbah debu pemotongan marmer (waste marble dust) limbah serbuk beton (concrete waste powder) dan limbah batu bata (brick waste powder) tidak hanya digunakan sebagai bahan tambahan ataupun pengganti sebagian agregat dan semen, tetapi juga mengurangi dampak dari limbah terhadap lingkungan 


\section{TINJAUAN PUSTAKA}

\section{A. Self Compacting Concrete}

Self Compacting Concrete adalah beton yang dapat memadat dengan sendirinya tanpa adanya segregasi pada beton. Menurut Okumara \& Ouichi (2003) ada 3 metode pembuatan beton self compacting, yaitu:

\section{Minimum $w /$ binder}

2. Membatasi jumlah agregat

\section{Aplikasi aditif}

Pembatasan jumlah agregat dilakukan pada agregat kasar, dan penambahan jumlah bahan pengikat adalah cara agar beton ini mudah dipadatkan. Dari gambar 2.1 dapat dilihat komposisi self compacting concrete yang dikeluarkan oleh Okumara \& Ouichi (2003)

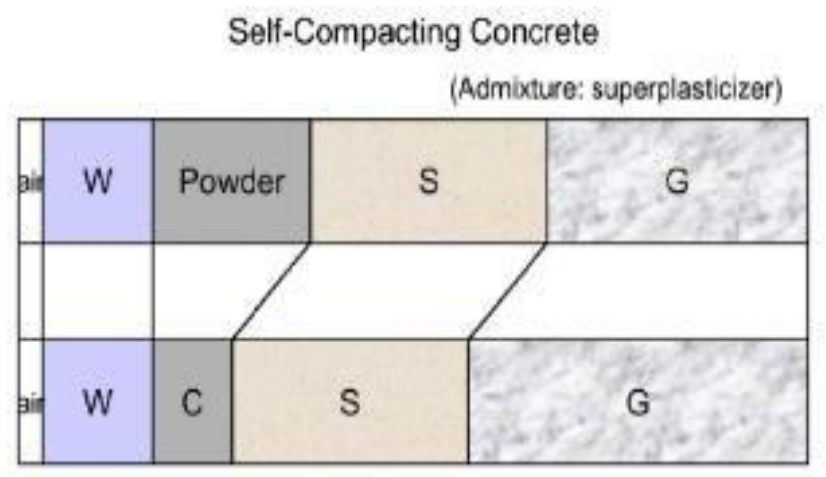

Conventional Concrete

Gambar 1 Perbandingan beton normal dan beton SCC (Okumara, 2003)

\section{B. Brick Waste Powder}

Batu bata adalah salah satu bahan bangunan, yang biasa digunakan di Indonesia, yang terbuat dari tanah liat dan dituang dengan suhu tinggi hingga batu bata menjadi sangat kering dan kemerahan. Seiring berjalannya waktu, limbah batu bata terus meningkat dengan semakin banyaknya bangunan tua yang dihancurkan. Limbah batu bata biasanya diisi tanah sehingga tidak hanya menempati ruang

yang berharga tetapi juga menyebabkan masalah lingkungan yang dapat dilihat pada Gambar 3 Dari penelitian sebelumnya, limbah bubuk bata dapat digunakan sebagai pengganti semen karena bata memiliki sifat pozzolan. Disajikan gambar 3 analisis kualitatif penelitian dari limbah batu bata. Karakteristik kimia brick waste powder adalah Silika oksida yang mampu memperkuat pengerasan pada beton.Keuntungan utama menggunakan limbah bubuk batu bata adalah untuk menggantikan semen yang juga mengurangi polusi dari produksi semen dan pembuangan batu bata (Ge, Gao, Sun, dan Zheng, 2012). Berikut disajikan gambar 2 limbah batu bata:

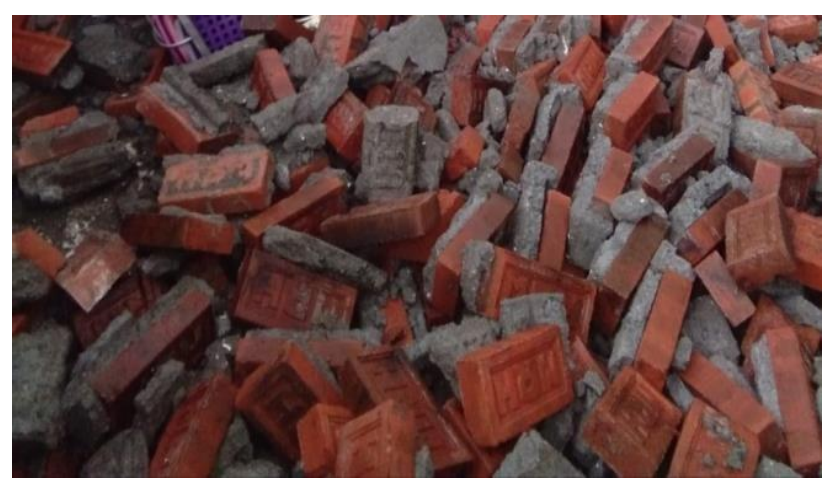

Gambar 2 Limbah bata dari bangunan yang hancur

Serbuk limbah batu bata dapat diklasifikasikan sebagai bahan pozzolan, karena penjumlahan $\mathrm{SiO} 2, \mathrm{Al}_{2} \mathrm{O}_{3}$ dan $\mathrm{Fe}_{2} \mathrm{O}_{3}$ lebih dari $70 \%$. Berikut disajikan tabel komposisi unsur kimia limbah batu bata. 


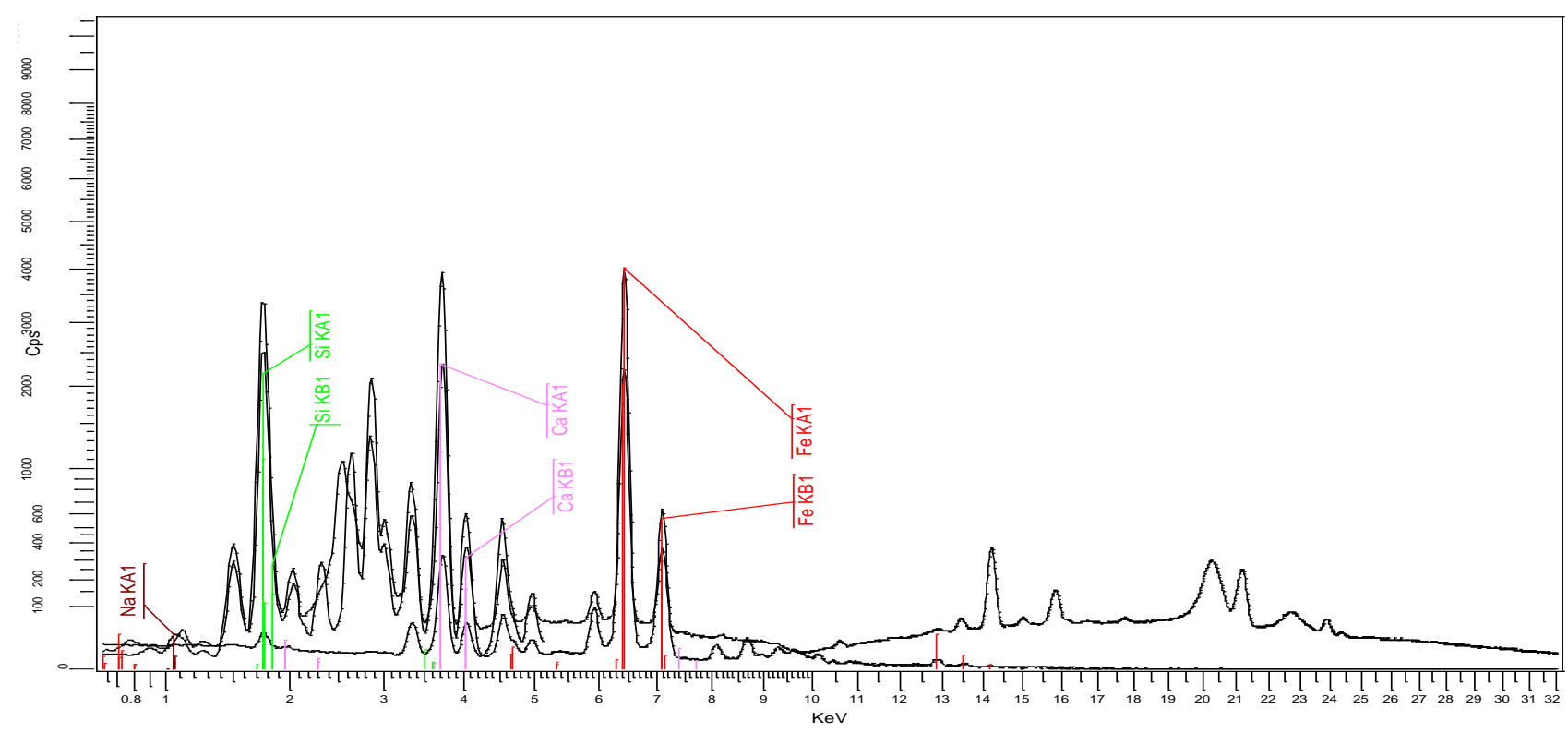

Gambar 3 Analisis kualitatif limbah serbuk batu bata (Sumber : Hasil penelitian penguji)

Tabel 1 Komposisi Kimia limbah batu bata

\begin{tabular}{|c|c|}
\hline Unsur & Prosentase \\
\hline $\mathrm{SiO}_{2}$ & 67.35 \\
\hline $\mathrm{Al}_{2} \mathrm{O}_{3}$ & 14.7 \\
\hline $\mathrm{Fe}_{2} \mathrm{O}_{3}$ & 7.83 \\
\hline $\mathrm{CaO}$ & 2.19 \\
\hline $\mathrm{MgO}$ & 1.67 \\
\hline $\mathrm{SO}_{3}$ & 0.15 \\
\hline $\mathrm{Na}_{2} \mathrm{O}+\mathrm{k}_{2} \mathrm{O}$ & 1.12 \\
\hline
\end{tabular}

Sumber : (bediako, 2018)

\section{Waste Marble Dust}

Dalam Bahasa Indonesia yaitu limbah debu pemotongan marmer, digunakan sebagai pengganti semen karena kemampuannya untuk mengikat (Ergun A, 2010). Tetapi, semua penelitian yang telah dilakukan menyatakan bahwa dapat menurunkan kekuatan pada umur akhir karena pengenceran terhadap $\mathrm{C}_{2} \mathrm{~S}$ dan $\mathrm{C}_{3} \mathrm{~S}$
(Turker et al, 2002). Berbeda dengan penelitian dimana waste marble dust digunakan sebagai pengganti agregat halus, disajikan gambar 5 analisis kualitatif limbah debu pemotongan marmer. Karakteristik kimia waste marble dust adalah kalsium oksida yang mampu memperkuat pengerasan pada beton. Ditemukan bahwa limbah pemotongan marmer memiliki banyak keuntungan seperti menurunkan porositas, menambah workability dan meningkatkan kekuatan umur awal (Demirel B, 2010). Disajikan gambar 4 limbah debu pemotongan marmer dibawah ini:

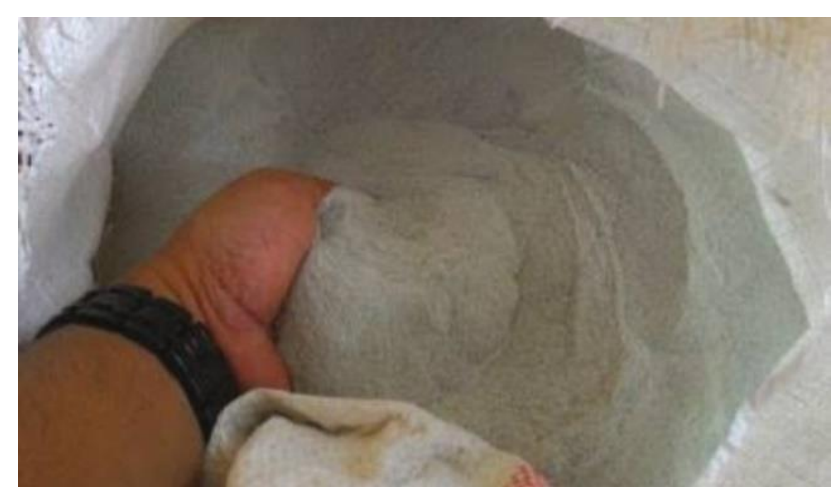

Gambar 4 limbah debu pemotongan marmer 


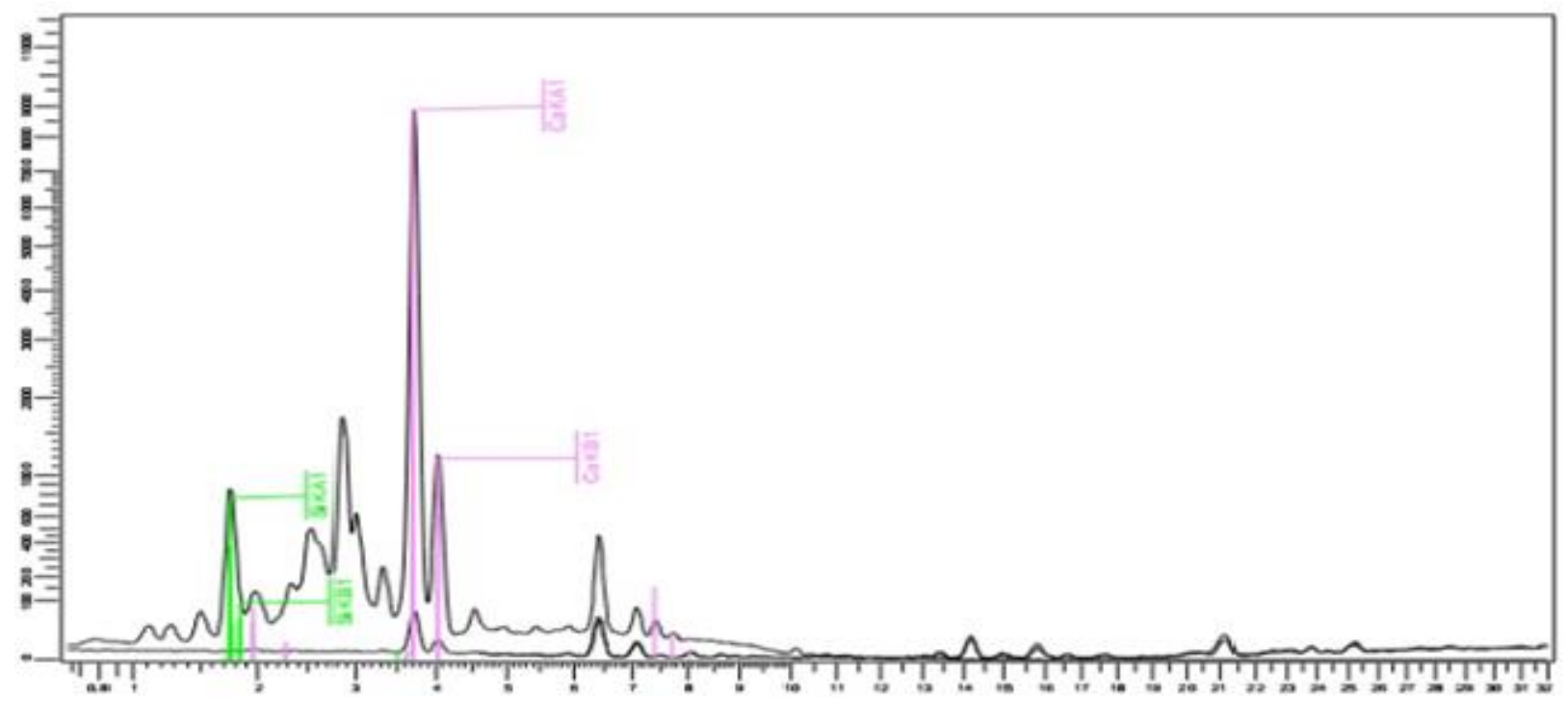

Gambar 5 Analisis kualitatif limbah debu pemotongan marmer

(Sumber : Hasil penelitian penguji)

Tabel 2 Kandungan kimia waste marble dust

\begin{tabular}{|l|c|}
\hline \multicolumn{1}{|c|}{ Unsur kimia } & $\begin{array}{c}\text { Kandungan } \\
(\%)\end{array}$ \\
\hline Silikon dioksida $\left(\mathrm{SiO}_{2}\right)$ & 0,13 \\
\hline $\begin{array}{l}\text { Aluminium dioksida } \\
\left(\mathrm{AlO}_{3}\right)\end{array}$ & 0,31 \\
\hline Feri oksida $\left(\mathrm{FeO}_{3}\right)$ & 0,04 \\
\hline Kalsium oksida $(\mathrm{CaO})$ & 55,07 \\
\hline Magnesium oksida $(\mathrm{MgO})$ & 0.36 \\
\hline Kalium oksida $\left(\mathrm{K}_{2} \mathrm{O}\right)$ & 0,01 \\
\hline Sulfur trioksida $\left(\mathrm{SO}_{3}\right)$ & 0,08 \\
\hline \multicolumn{1}{|c|}{$(\mathrm{lol})$} & 44 \\
\hline
\end{tabular}

\section{Concrete Waste Powder}

Concrete waste powder adalah serbuk limbah beton. Jutaan ton limbah beton dihasilkan setiap tahun di Indonesia terdapat limbah beton yang tidak difungsikan secara maksimal, dikarena alasan pembongkaran bangunan lama, penghancuran bangunan dan struktur bencana, penghapusan beton yang tidak berguna dari bangunan, trotoar jalan, dan sebagainya. Metode destruktif pengujian struktur yang ada (Ganiron, 2017). Karakteristik kimia concrete waste powder adalah Silika oksida yang mampu memperkuat pengerasan pada beton. Dalam penelitian ini, concrete waste powder diperlukan sebagai akselerator untuk hidrasi semen untuk membantu nukleasi yang mampu meningkatkan kekuatan tekan awal. Menghancurkan limbah beton secara mekanis untuk menghasilkan agregat beton daur ulang sebagai substitusi agregat alami telah menjadi solusi praktis untuk daur ulang limbah beton (Fathifazl et al., 2011; Medina et al., 2014) 
Tabel 3 Kandungan kimia limbah bubuk beton

\begin{tabular}{|l|l|}
\hline Unsur kimia & Kandungan (\%) \\
\hline $\mathrm{SiO}_{2}$ & $51,8 \%$ \\
\hline $\mathrm{CaO}$ & $22,8 \%$ \\
\hline $\mathrm{Al}_{2} \mathrm{O}_{3}$ & $13,6 \%$ \\
\hline $\mathrm{Fe}_{2} \mathrm{O}_{3}$ & $5.6 \%$ \\
\hline $\mathrm{MgO}$ & $1.4 \%$ \\
\hline $\mathrm{SO}_{3}$ & $0,8 \%$ \\
\hline $\mathrm{TiO}_{2}$ & $0,7 \%$ \\
\hline $\mathrm{K}_{2} \mathrm{O}$ & $2,6 \%$ \\
\hline
\end{tabular}

Self compacting concrete dikurangi dan diganti dengan menggunakan bubuk limbah bata, dan limbah serbuk beton dengan 15\%, 15\%, dan limbah debu pemotongan marmer disubstitusikan sebagai pengganti aggregate halus sebesar $30 \%$ menciptakan beton self compacting concrete ramah lingkungan. Teknik pengumpulan data pada penelitian ini

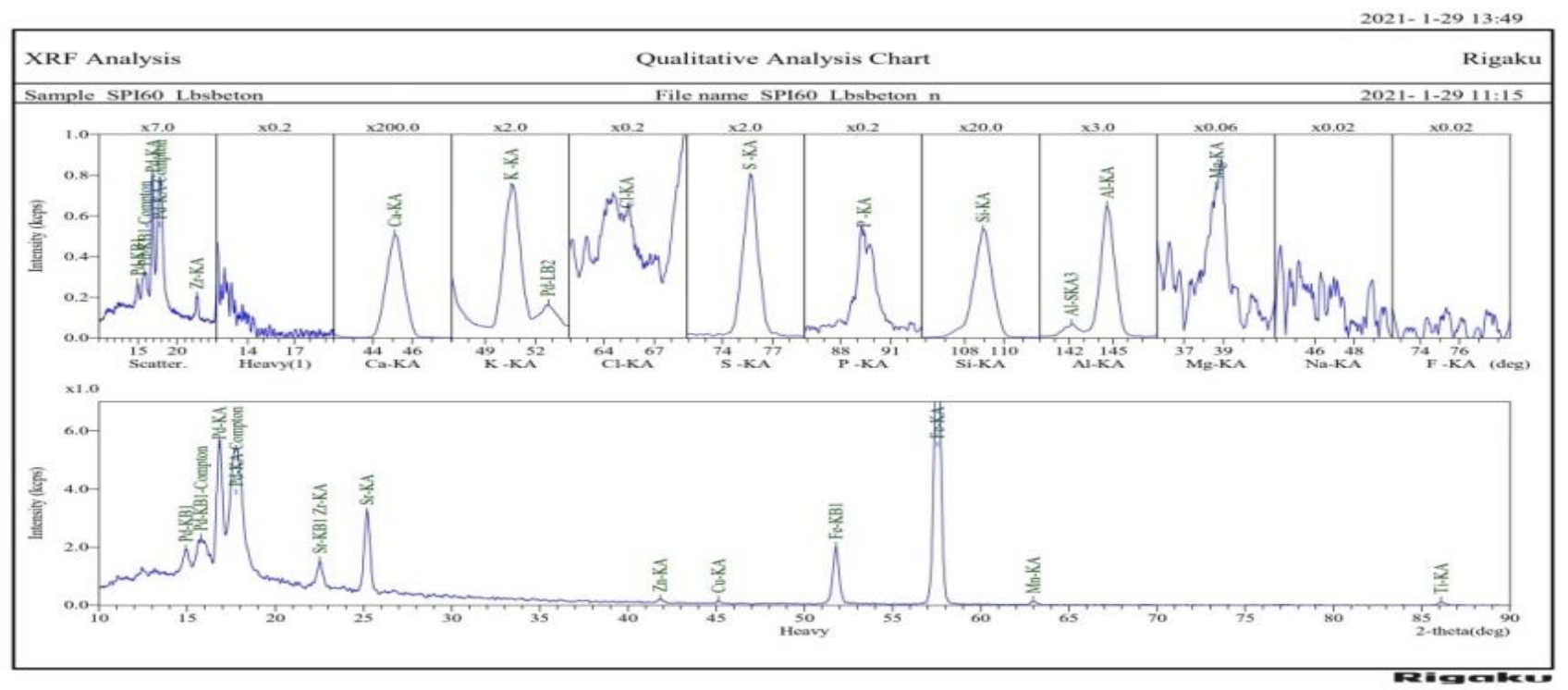

Gambar 6 Qualitative Analysis Chart

(Sumber : Hasil penelitian penguji)

\section{METODE PENELITIAN}

\section{A. Tempat pelaksanaan}

Pengujian dan pelaksanaan, uji coba trial di Laboratorium Fakultas Teknik Universitas Tunas Pembangunan Surakarta.

\section{B. Metode pengumpulan data}

Dalam bab ini, penggunaan material untuk substitusi semen dan pengganti agregat halus akan dianalisis. Kandungan semen dalam beton dilakukan dengan tinjauan pustaka dan melakukan beberapa percobaan di laboratorium Fakultas Teknik Universitas Tunas Pembangunan Surakarta. Tujuan mempelajari tinjauan literatur dan bereksperimen di laboratorium adalah untuk mengumpulkan data yang relevan yang akan diterapkan dalam penelitian. 


\section{Data material dan bahan yang digunakan}

a. Semen

Semen adalah pengikat, zat yang digunakan dalam konstruksi yang mengeras serta dapat mengikat bahan lain menjadi satu. Unsur terpenting dalam semen adalah:

1. Tricalcium Silikat $\left(\mathrm{C}_{3} \mathrm{~S}\right)$

2. Dicalcium Silikat $\left(\mathrm{C}_{2} \mathrm{~S}\right)$

3. Tricalcium Aluminate $\left(C_{3} A\right)$

4. Tetracalcium Aluminoferrite $\left(\mathrm{C}_{4} \mathrm{AF}\right)$

Semen yang digunakan dalam penelitian ini adalah dari PCC Semen Tiga Roda dengan berat jenis 3.15

\section{b. Aggegate Halus}

Aggregate halus sering disebut dengan pasir. Agregat halus berfungsi sebagai pengisi yang berasal dari pasir alam. Berdasarkan pengujian material aggregate halus, persyaratan agregat halus untuk campuran beton adalah:

1. Aggregate halus tidak boleh mengandung lebih dari $5 \%$ tanah liat.

2. Tempat penyimpanan pasir harus dipisahkan dari material lainnya.

3. Pasir yang digunakan adalah Muntilan dari Merapi

4. Gravity Spesific: 2,6

\section{c. Aggegate Kasar}

Aggregate kasar yang sering digunakan dalam campuran beton adalah kerikil dan batu pecah. Agreggate kasar adalah partikel yang tertahan pada saringan 4,75 mm. Kualitas agreggate kasar dapat diukur dengan uji abrasi Los Angeles dimana hasilnya tidak boleh lebih dari $50 \%$ dari berat awalnya (ENI 12620). Pasir yang tersedia secara lokal dari Klaten digunakan dengan berat jenis 2,65, Persyaratan aggregate kasar untuk campuran beton adalah:

1. Agreggate kasar berasal dari partikel tajam dan keras, kedap air, dan berbentuk kubus.

2. Split yang digunakan adalah Sentolo, Yogyakarta

3. Agreggate kasar tidak boleh mengandung lebih dari $1 \%$ tanah liat terhadap berat keringnya

\section{d. Air}

Air diperlukan pada pembuatan beton untuk memicu proses kimiawi semen, membasahi agregat dan memberikan kemudahan dalam pekerjaan beton. Syarat air yang dapat digunakan adalah bersih, bebas dari bahan organik seperti minyak, garam, alkali, atau bahan lainnya yang dapat merusak beton. Sebaiknya dipakai air tawar yang dapat diminum. Air yang digunakan dalam pembuatan beton tidak boleh mengandung ion klorida dalam jumlah yang membahayakan (ACI 318-89:2-2)

\section{e. Consol P102HE}

Consol P102 HE adalah superplasticizer unik serbaguna yang sangat cocok untuk mengoptimalkan siklus curing dengan memerpendek waktu curing atau mengurangi waktu curing produksi beton pracetak. Selain itu, ini memberikan pengurangan air yang sangat tinggi, kekuatan awal yang tinggi dan karakteristik aliran yang sangat baik.

P102 HE digunakan untuk : 
1. Berbagai macam aplikasi yang memerlukan pengembangan kekuatan awal.

2. Beton dengan ultra high water reduction (hingga 30\%).

3. Beton dengan performa tinggi

Tabel 4 pengujian aggregate Kasar

\begin{tabular}{|c|c|c|c|c|c|c|}
\hline $\begin{array}{c}\text { No. } \\
\text { Ayakan }\end{array}$ & $\begin{array}{c}\text { Berat } \\
\text { Ayakan } \\
\text { (Gram) }\end{array}$ & $\begin{array}{c}\text { Byakan } \\
+ \\
\text { Agregat } \\
\text { (Gram) }\end{array}$ & $\begin{array}{c}\text { Bgregat } \\
\text { (Gram) }\end{array}$ & $\begin{array}{c}\text { Tertahan } \\
(\%)\end{array}$ & $\begin{array}{c}\text { Tertahan } \\
\text { Kumulatif(\%) }\end{array}$ & $\begin{array}{c}\text { Lolos } \\
(\%)\end{array}$ \\
\hline $20.0 \mathrm{~mm}$ & 1250 & 1275 & 25 & 0.608273 & 0.608273 & 99.3917 \\
\hline $14.0 \mathrm{~mm}$ & 1070 & 2775 & 1705 & 41.48418 & 42.09246 & 57.9075 \\
\hline $10.0 \mathrm{~mm}$ & 1055 & 3030 & 1975 & 48.05353 & 90.14599 & 9.85402 \\
\hline $5.0 \mathrm{~mm}$ & 1145 & 1535 & 390 & 9.489051 & 99.63504 & 0.36496 \\
\hline $2.36 \mathrm{~mm}$ & 1070 & 1075 & 5 & 0.121655 & 99.75669 & 0.24331 \\
\hline dasar & 1000 & 1000 & 0 & 0 & 0 & 0 \\
\hline
\end{tabular}

Tabel 5 pengujian aggregate Halus

\begin{tabular}{|l|l|l|l|l|l|c|}
\hline $\begin{array}{c}\text { No. } \\
\text { Ayakan }\end{array}$ & \multicolumn{1}{|c|}{ Berat } & $\begin{array}{r}\text { Berat } \\
\text { Ayakan } \\
+ \\
\text { Agregat }\end{array}$ & Berat & Tertahan & Tertahan & Lolos \\
\hline & Agregat & & & \\
\hline $2.36 \mathrm{~mm}$ & 570 & 725 & 155 & 8.28877 & 8.2887701 & 91.7112 \\
\hline $1.18 \mathrm{~mm}$ & 495 & 670 & 175 & 9.35829 & 17.647059 & 82.3529 \\
\hline $0.6 \mathrm{~mm}$ & 535 & 1065 & 530 & 28.3423 & 45.989305 & 54.0107 \\
\hline $0.3 \mathrm{~mm}$ & 455 & 1050 & 595 & 31.8182 & 77.807487 & 22.1925 \\
\hline $0.15 \mathrm{~mm}$ & 485 & 775 & 290 & 15.508 & 93.315508 & 6.68449 \\
\hline $0.075 \mathrm{~mm}$ & 465 & 520 & 55 & 2.94118 & 96.256684 & 3.74332 \\
\hline Dasar & 350 & 405 & 55 & 2.94118 & 99.197861 & 0.80214 \\
\hline
\end{tabular}

\section{Mix Design}

Perhitungan Mix design beton inovasi Self Compacting Concrete menggunakan metode ACI 211.4r-93 1998

Pengujian berat jenis dilakukan berdasarkan pengujian dilaboratorium mengacu pada SNI 13-

6717-2002

Tabel 6 Mix Design

\begin{tabular}{|c|c|c|}
\hline Mutu & Berat jenis & Satuan \\
\hline Semen DCs & 3150 & $\mathrm{Kg} / \mathrm{m}^{3}$ \\
\hline $\begin{array}{l}\text { Brick waste } \\
\text { powder }\end{array}$ & 2560 & $\mathrm{Kg} / \mathrm{m}^{3}$ \\
\hline $\begin{array}{l}\text { Concrete waste } \\
\text { powder }\end{array}$ & 2460 & $\mathrm{Kg} / \mathrm{m}^{3}$ \\
\hline Pasir & 2600 & $\mathrm{Kg} / \mathrm{m}^{3}$ \\
\hline Split & 2650 & $\mathrm{Kg} / \mathrm{m}^{3}$ \\
\hline $\begin{array}{l}\text { Waste marble } \\
\text { dust }(30 \%)\end{array}$ & 2300 & $\mathrm{Kg} / \mathrm{m}^{3}$ \\
\hline $\begin{array}{l}\text { Water Binder } \\
\mathrm{w} / \mathrm{b} \text { (Fas) }\end{array}$ & \multicolumn{2}{|c|}{$0,27 \%$} \\
\hline \multirow[b]{2}{*}{ Material } & Volume & Volume \\
\hline & $1 \mathrm{~m}^{3}(\mathrm{Kg})$ & $\begin{array}{c}\text { Silinder } \\
(0,0052) \\
\mathbf{K g}\end{array}$ \\
\hline Kadar udara, & $1 \%$ & $1 \%$ \\
\hline Kadar air & 171,818 & 0.202 \\
\hline Semen pcc & 350 & 2,366 \\
\hline $\begin{array}{l}\text { Brick waste } \\
\text { powder }\end{array}$ & 95,45 & 0,645 \\
\hline $\begin{array}{l}\text { Concrete waste } \\
\text { powder }\end{array}$ & 95,45 & 0,645 \\
\hline $\begin{array}{l}\text { Agreggate } \\
\text { balus (pasir) }\end{array}$ & 674,58 & 4,560 \\
\hline $\begin{array}{l}\text { Waste marble } \\
\text { dust }\end{array}$ & 105,307 & 0,711 \\
\hline Superplasticizer & 14,636 & 0,098 \\
\hline $\begin{array}{l}\text { Agreggate } \\
\text { basar (split) }\end{array}$ & 746,664 & 5,047 \\
\hline
\end{tabular}




\section{E. Alur Penelitian}

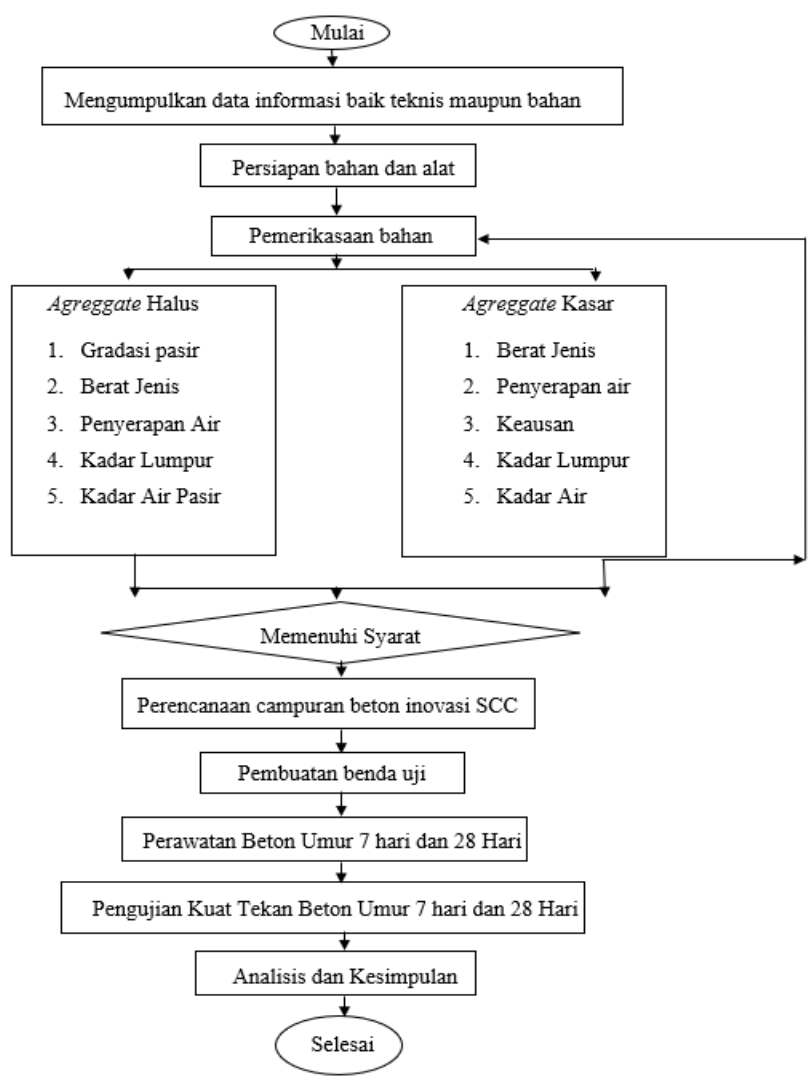

Gambar 7 Alur Pembuatan Beton

\section{HASIL DAN PEMBAHASAN}

\section{A. Rencana Anggaran Biaya (RAB)}

Tabel 7 Rencana Anggaran Biaya Pembuatan Beton Self compacting concrete

\begin{tabular}{|c|c|c|c|c|c|}
\hline \multirow[b]{2}{*}{ Material } & \multirow{2}{*}{$\begin{array}{c}\text { Tim } \\
\text { Harga } \\
\text { Satuan } \\
(\mathrm{Kg})\end{array}$} & \multicolumn{2}{|c|}{ BETON } & \multicolumn{2}{|c|}{ BETON KONVENSIONAL } \\
\hline & & $\begin{array}{c}\text { Kebutuhan } \\
\text { per } \mathrm{m}^{3}\end{array}$ & Harga & $\begin{array}{c}\text { Kebutuhan } \\
\text { per } \mathrm{m}^{3}\end{array}$ & Harga \\
\hline Kadar Air & $\begin{array}{l}\mathrm{Rp} \\
6\end{array}$ & 171,818 & Rp.1030 & 182 & Rp. $1.092,00$ \\
\hline Semen PCC & $\begin{array}{l}\text { Rp } \\
1.500\end{array}$ & 350 & Rp. $525.000,00$ & 650 & Rp. $975.000,00$ \\
\hline Consol P102 HE & $\begin{array}{l}\text { Rp } \\
10.000\end{array}$ & 14,636 & Rp. $146.360,00$ & 16,25 & Rp. $162.500,00$ \\
\hline $\begin{array}{l}\text { Agreggate Halus } \\
\text { (pasir) }\end{array}$ & $\begin{array}{l}\mathrm{Rp} \\
1000\end{array}$ & 598,125 & Rp. $598.125,00$ & 782,6 & Rp. $782.600,00$ \\
\hline Waste marble dust & $\begin{array}{l}\mathrm{Rp} \\
14,45\end{array}$ & 226,762 & Rp. $3.276,00$ & - & - \\
\hline Brick waste powder & $\begin{array}{l}\text { Rp } \\
20\end{array}$ & 95,45 & Rp. $1.909,00$ & - & - \\
\hline $\begin{array}{l}\text { Concrete waste } \\
\text { powder }\end{array}$ & $\begin{array}{l}\text { Rp } \\
25\end{array}$ & 95,45 & Rp. $2.300,00$ & - & - \\
\hline $\begin{array}{l}\text { Agreggate Kasar } \\
\text { (Split) }\end{array}$ & $\begin{array}{l}\mathrm{Rp} \\
500\end{array}$ & 803.904 & Rp. $401.952,00$ & 797,6 & Rp $398.800,00$ \\
\hline & & Total & Rp 1.679.952,00 & Total & \begin{tabular}{|l|} 
Rp 2.319.992,00 \\
\end{tabular} \\
\hline & & & & Save & Rp $640.040,00$ \\
\hline
\end{tabular}

sumber : HSPK Kota Surakarta

\section{B. Analisis Dampak beton Self compacting concrete:}

\section{a. Aspek Ekonomi}

Dengan menggunakan serbuk limbah beton, serbuk limbah bata, dan limbah debu marmer dapat menghemat biaya dibandingkan dengan menggunakan beton konvensional dapat menekan biaya penggunaan yang berlebihan dalam pembuatan beton sebesar Rp. 640.040,00 / $\mathrm{m}^{3}$. Hal ini menunjukkan cukup banyak, selain memanfaatkan bahan-bahan yang menjadi limbah yang mudah didapatkan.

b. Aspek lingkungan

Serbuk limbah beton dan limbah batu bata biasanya tidak digunakan pada saat pembongkaran rumah akibat renovasi atau bencana alam. Sebagian besar dibuang karena tidak ada yang tahu cara memanfaatkan limbah beton, serta limbah debu serpihan marmer dan abu sekam padi, yang sering dibuang ke sungai dan mencemari. lingkungan, jadi ini adalah salah satu solusi untuk masalah analisis dampak. lingkungan di Indonesia yang akan dikembangkan, Produksi semen menyumbang 57\% emisi karbondioksida (Sakai 2008). Penggunaan bubuk limbah batu bata sebagai SCM (supplementary cementitious material) dapat mengurangi biaya produksi beton. Mereka bisa memproduksi beton dengan biaya lebih murah. Pemanfaatan limbah material ini dapat mengurangi pemanasan global, mengurangi jumlah limbah yang ada, karena abu sekam padi bertambah setiap tahun dan karena seperti yang kita ketahui bahwa produksi semen merupakan 
penyumbang gas karbondioksida terbesar di dunia maka akan membahayakan lingkungan. dengan mengurangi, membarui, menggunakan kembali, dan mendaur ulang berdasarkan konsep 4R (Reduce, Refurbish, Reuse, Recycle)

c. Aspek Penerapan di masyarakat

Berdasarkan penelitian dengan pemanfaatan limbah khas daerah yaitu limbah debu pemotongan marmer, limbah serbuk batu bata dan limbah serbuk beton yang mampu mengurangi pencemaran lingkungan serta memliki dampak positif terhadap masyarakat, karena masyarakat bisa berkerja sama dengan industry marmer yang ada di wilayah Indonesia serta bekerja sama dengan pihak konstruksi bangunan apabila memiliki limbah.

\section{Tabel hasil pengujian limbah terhadap beton.}

Tabel 8 Pengujian brick waste powder

\begin{tabular}{|c|c|c|}
\hline \multirow{2}{*}{ No. } & Presentase BWP & $\begin{array}{c}\text { Compressive } \\
\text { Strength 1 Day }\end{array}$ \\
\cline { 3 - 3 } & & $(\mathrm{MPa})$ \\
\hline 1 & $0 \%$ & 4 \\
\hline 2 & $5 \%$ & 5,2 \\
\hline 3 & $10 \%$ & 5,31 \\
\hline 4 & $15 \%$ & 7,3 \\
\hline 5 & $20 \%$ & 6,41 \\
\hline
\end{tabular}

Tabel 9 Pengujian waste marble dust

\begin{tabular}{|c|c|c|}
\hline \multirow{2}{*}{ No. } & \multirow{2}{*}{$\begin{array}{c}\text { Presentase } \\
\text { WMD }\end{array}$} & $\begin{array}{c}\text { Compressive } \\
\text { Strength 1 Day }\end{array}$ \\
\cline { 3 - 3 } & & $(\mathrm{MPa})$ \\
\hline 1 & $0 \%$ & 10 \\
\hline 2 & $5 \%$ & 10,45 \\
\hline 3 & $10 \%$ & 11,12 \\
\hline 4 & $15 \%$ & 13,17 \\
\hline
\end{tabular}

\begin{tabular}{|c|c|c|}
5 & $20 \%$ & 15,32 \\
\hline 6 & $25 \%$ & 17,51 \\
\hline 7 & $30 \%$ & 19,23 \\
\hline 8 & $35 \%$ & 21,43 \\
\hline 9 & $40 \%$ & 20,52 \\
\hline
\end{tabular}

Tabel 10 Pengujian concrete waste powder

\begin{tabular}{|c|c|c|}
\hline \multirow{2}{*}{ No. } & \multirow{2}{*}{$\begin{array}{c}\text { Presentase } \\
\text { CWP }\end{array}$} & $\begin{array}{c}\text { Compressive } \\
\text { Strength 1 Day }\end{array}$ \\
\cline { 3 - 3 } & & $(\mathrm{MPa})$ \\
\hline 1 & $0 \%$ & 3,4 \\
\hline 2 & $5 \%$ & 4,32 \\
\hline 3 & $10 \%$ & 6,32 \\
\hline 4 & $15 \%$ & 8,2 \\
\hline 5 & $20 \%$ & 7,52 \\
\hline
\end{tabular}

\section{KESIMPULAN/RINGKASAN}

1. Berdasarkan penelitian yang telah dilakukan, waste marble dust dapat digunakan sebagai pengganti agregat halus sedangkan brick waste powder, dan concrete waste powder digunakan sebagai substitusi semen.

2. Pengaruh limbah pemotongan marmer yaitu tidak terjadi penurunan kekuatan dan dapat meningkatkan workability jika dibandingkan dengan beton tanpa limbah pemotongan marmer.

3. Pemakaian dalam jumlah besar mengurangi produksi semen, sehingga menggurangi gas rumah kaca yang dihasilkan dari produksi semen.

4. Dengan menggunakan limbah pemotongan marmer (waste marble dust), limbah bubuk beton (concrete waste powder), dan limbah batu bata (brick waste powder) akan menghemat waktu, ekonomis serta ramah lingkungan. 
5. Pemanfaatan limbah pemotongan marmer limbah bubuk beton, limbah beton, dan limbah batu bata untuk beton inovasi akan menghemat pembuatan beton sebesar Rp 640.040,00

\section{DAFTAR PUSTAKA}

Okamura, H., Ouchi, M., 2003. Selfcompacting Concrete, Advanced concrete technology.

Neville, A.M., Brooks, J.J., 1987. Concrete Technology. New York: Longman Scientific \& Technical.

Nugraha, P., Antoni, 2004. Teknologi Beton.Yogyakarta: ANDI

Reni, Y.C., Hastuti, R., Darmawan, A., Kajian Pengaruh Penambahan Kalsium Oksida $(\mathrm{CaO})$ terhadap Suhu Reaksi dan Kuat Tekan Semen Portland, Semarang: Universitas Diponegoro.

Ergün, A., 2010. Effects of the usage of diatomite and waste marble powder as partial replacement of cement on the mechanical properties of concrete, Turkey: Afyon Kocatepe University.

Demirel, B., (2010). The effect of the using waste marble dust as fine sand on the mechanical properties of the concrete, Turkey: Firat University

Entwicklung, Dauerhaftigkeit und Berechnung Ultra-Hochfester Beton (UHPC), Kassel University Press, Schriften Reihe Baustoffe und Massivbau Heft.
G. Koenig, N. Viet Tue, M. Zink (2001). Hochleistungsbeton, Bemessung.Ernst \& Sohn. Herstellung und Anwendung

Ge, Z., Gao, Z., Sun, R., \& Zheng, L. 2012. Campuran desain beton dengan bubuk batu bata daur ulang menggunakan metode desain ortogonal. Construction and Building Materials.

Poon, C.S., \& Chan, D. 2006. Penggunaan agregat beton daur ulang yang layak dan bata yang dihancurkan sebagai dasar jalan yang tidak terikat. Constr. Build. Mater.

Poon, C.S., \& Chan, D. 2006. paving blok dibuat dengan agregat beton daur ulang dan batu bata yang dihancurkan. Constr. Build. Mater.

Suhendro, B. 2014. Menuju Green Concrete untuk lingkungan berkelanjutan yang lebih baik. Procedia Engineering, 95, 305-3

Ashish, D. K. (2018) Concrete made with waste marble powder and supplementary cementitiuos material for sustainable development. Journal of cleaner production 